\title{
OPTIMIZATION OF RAPID PROTOTYPING TECHNOLOGY FOR ADVANCED MEDICAL APPLICATIONS
}

\author{
M. Šljivic ${ }^{1, *}$, M. Stanojević ${ }^{1}$, N. Grujović ${ }^{2}$, R. Radonjić ${ }^{1}$ \\ ${ }^{1}$ University of Banja Luka, Faculty of Mechanical Enginering, Bulevar \\ Vojvode Stepe Stepanovića 71, Banja Luka, Republic of Srpska, B\&H \\ ${ }^{2}$ University of Kragujevac, Faculty of Mechanical Engineering, \\ Sestre Janjić 6, Kragujevac, Serbia
}

\begin{abstract}
The application of the two technologies: reverse engineering and rapid prototyping is emerging rapidly in the medical applications. These engineering methods have especially shown fast advancement in the following applications: in very complex preparation of computer aided surgery, computer guided implantology, non-invasive diagnostic from CT and MRI scans, design of customized implants, maxillofacial surgery, esthetic and reconstructive plastic surgery, orthopedic surgery, etc. This research has a multidisciplinary approach; it requires a team work of experts from various scientific fields such as CAD design and virtual engineering, digital image processing, medicine, implantology. Only a very few applicative pioneer steps have been made so far in Republic of Srpska, Bosnia and SE Europe in general.

The aim of this research is to make a contribution to the optimization of all three phases: preprocessing, processing and post-processing in the process chain of reverse engineering - rapid prototyping in the medical applications. The optimal process of rapid prototyping has been defined for different medical input data and formats. The process includes internal 3d reconstruction of CT and MRI scanning in DICOM format, such as applications in orthopedic surgery, maxillofacial surgery, prosthetic dentistry, such as complex or total prosthesis, as well as the external surface reconstruction by $3 \mathrm{~d}$ scanning, such as esthetic surgery and reconstruction plastic surgery or dentistry based on $3 \mathrm{~d}$ scanning from elastic silicone impression.
\end{abstract}

Keywords: optimization, preprocessing and post-processing, reverse engineering, computer guided implantology.

\section{INTRODUCTION}

The application of rapid prototyping technology is emerging rapidly in medical applications, especially in implantology.

However, the rapid prototyping process in medical applications has some specific features in comparison with typical technical usage. For example, pre-processing preparation with 3D scanning by volumetric computer tomography is significantly different than the one in machine industry, where the engineers use usually CAD parametric software or the reverse engineering with surface scanners. Furthermore, surface of medical bodies modeled by RP, also shows significant difference in surface rough- ness and the degree of curvature is so variable. Also, every medical body is unique, and in every case, it is necessary to process a new 3D scanning. In addition, there are many internal features like various and complex cavities, gaps and channels.

So, all major aspects of rapid prototyping should be considered: nature of application, features of methods, input models of data, material variations for processing of prototype models.

Then, it is important to identify, analyze and optimize the rapid prototyping process in accordance with applications.

In the following figure, one can see the major aspects necessary to be considered in rapid prototyping. 


\begin{tabular}{|c|c|c|}
\hline \multicolumn{3}{|c|}{ MAJOR ASPECTS OF RAPID PROTOTYPING } \\
\hline I. APPLICATIONS & \multicolumn{2}{|c|}{ II. METHOD } \\
\hline 1. Design & \multirow{3}{*}{$\begin{array}{l}\text { 1. Photo } \\
\text { Curing }\end{array}$} & $\begin{array}{l}\text { Single Laser } \\
\text { Beam }\end{array}$ \\
\hline 2. Engineering and Analysis & & Double Laser \\
\hline 3. Tooling and Manufacturing & & Masked Lamp \\
\hline \multirow{3}{*}{$\begin{array}{l}\text { Biomedical, Consumer, } \\
\text { Electrical and Electronics, } \\
\text { Automotive, Aerospace } \\
\text { Products, etc. }\end{array}$} & \multicolumn{2}{|c|}{ 2. Cutting and Glueing/Joining } \\
\hline & \multicolumn{2}{|c|}{$\begin{array}{l}\text { 3. Melting and Solidifying/ } \\
\text { Fusing }\end{array}$} \\
\hline & \multicolumn{2}{|c|}{ 4. Joining/Binding } \\
\hline III. INPUT & \multicolumn{2}{|c|}{ IV. MATERIAL } \\
\hline 1. Computer model - CAD & \multicolumn{2}{|c|}{ 1. Laminates, Pellets, Wire } \\
\hline 2. Physical Object - data & \multicolumn{2}{|l|}{ 2. Powder } \\
\hline $\begin{array}{l}\text { acquilition as Reverse } \\
\text { Engineering by Point Data }\end{array}$ & \multicolumn{2}{|l|}{ 3. Liquid } \\
\hline digitizer, etc.) & \multirow{3}{*}{\multicolumn{2}{|c|}{$\begin{array}{l}\text { Paper, Resins, Nylon, ABS, } \\
\text { Wax, Metals, Ceramics, etc. }\end{array}$}} \\
\hline Meshing - STL files & & \\
\hline $\begin{array}{l}\text { Slicing/Layer Information - SLI } \\
\text { files }\end{array}$ & & \\
\hline
\end{tabular}

Figure 1. Major aspects of rapid prototyping

As already mentioned, medical applications have some specific aspects to be considered. For medical applications with more cavities, it is recommendable to use the RP methods without support structures like 3D Printing and SLS, as opposed to SLA and some MultiJet methods. The problem is presented by very difficult post-processing of internal surfaces of models. For example, a similar problem does not exist with 3D printing, as it uses the powder as material, which is cured by liquid binding material. So the rest of the surrounding powder is very easily removed by using a special cleaning device.

On the other hand, preprocessing steps should also be considered concerning the input data. Input in medical applications is provided by the CT - computer tomography or MRI - magnetic resonance imaging. So, the input data is of the kind of 2,5 volumetric data, processed in equidistant slices. That is why it is necessary. This data should be converted from the "voxels" into the 3D surface-type meshes by reverse engineering methodology.

The rapid prototyping process is identified in the process chain, and then analyzed in the following chapter, taking into consideration the above mentioned features of medical applications,

\section{PROCESS CHAIN OF RAPID PROTOTYPING}

In general, the rapid prototyping process comprises 3 groups of actions: preprocessing, processing and post-processing. According to the mentioned division there are 3 kinds of generated errors: preprocessing errors, processing errors and post-processing errors.

The figure below presents the complete structure of process chain.

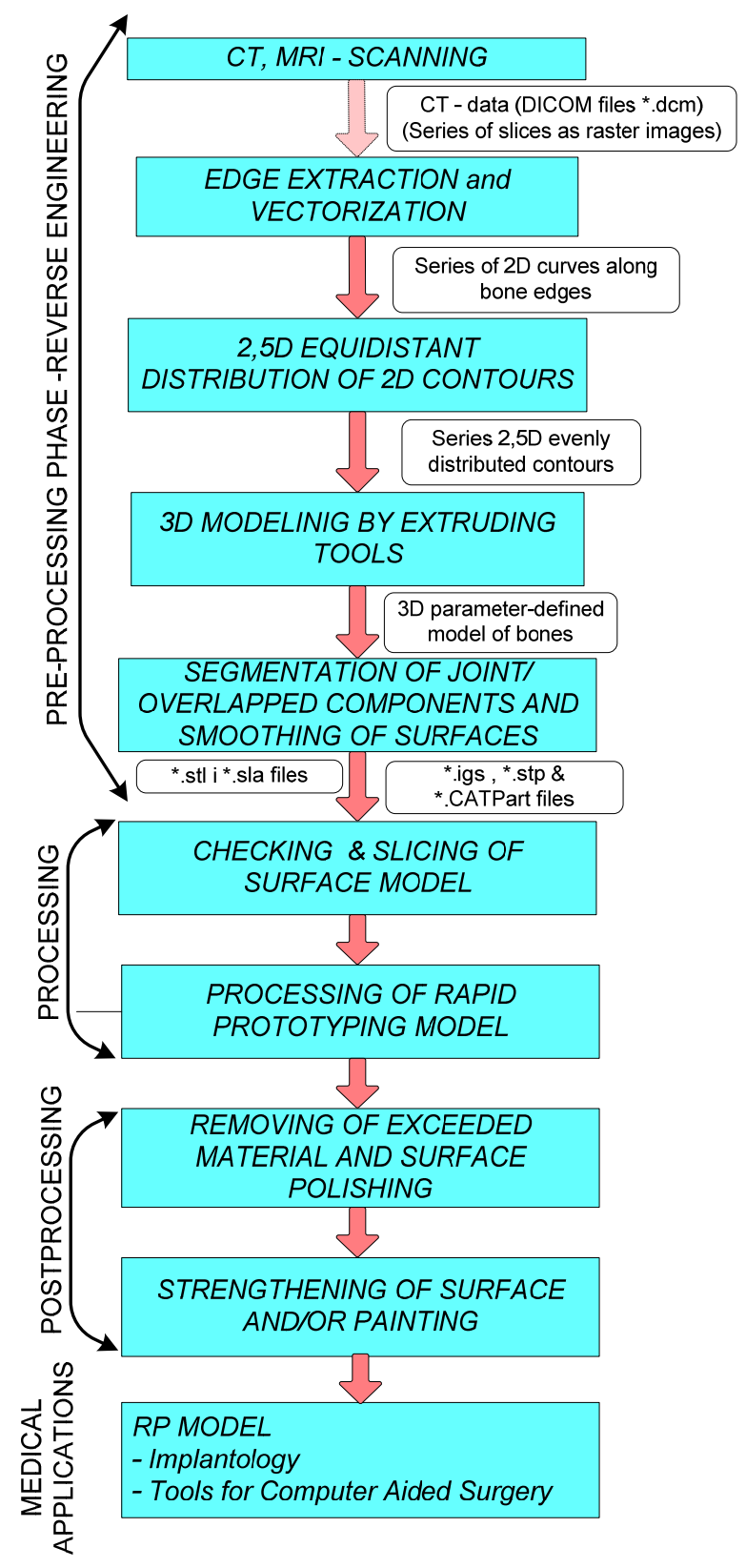

Figure 2. Major aspects of rapid prototyping

The rapid prototyping process in medical applications has specific features related to the provision of data on samples. 
Firstly, preprocessing steps should be considered referring to the input data like DICOM files, scanning data, image filtering and image reconstruction, edge detection, extraction of components, conversion from $2 \mathrm{D}$ into $3 \mathrm{D}$ data and smoothing of surfaces. This processing segment is in focus of the current stage of research. Input in medical applications is provided by the CT - computer tomography or MRI - magnetic resonance. It is analyzed in details in chapter 3 .

\section{ANALYSIS OF RP PROCESS CHAIN RELATING TO THE ERROR GENERA- TION}

RP process chain comprises numerous and complex phases; in the current stage of research, the focus is on preprocessing group of activities and their major errors.

\subsection{MPR - multi planar reconstruction}

Multi planar reconstruction is based on the standardized CT data, which consists of a series of raster (bitmap) images as slices/sections of the observed human body. These images are distributed in equidistant series on the $\mathrm{CT}$ axis direction.

Distance between 2 slices determines the volumetric resolution. Selection of resolution and other standards are reviewed in ASTM E1441 -00(2005) Standard Guide for Computed Tomography.

Smaller resolution enables better 3D reconstruction, but the scanning time is increased and as a consequence, the patient is exposed to higher radiation, the amount of data is increased as well as the necessary time for data processing and analysis, etc.

MPR data is very simple in comparison with the other file formats, because it is just a common series of raster images. Consequently, there is a problem of visualization of the third dimension. This issue is very serious for the body tissues with high topographic complexity.

By MPR reconstruction it is possible only to measure and make some diagnostic work in the plane of slices (2D approach).

According to the practical experience and CT standards with detail level of various body tissues, $\mathrm{CT}$ collimation and resolution range (common values $0,5 \mathrm{~mm}, 1 \mathrm{~mm}, 1,5 \mathrm{~mm}, 3 \mathrm{~mm}$ and $6 \mathrm{~mm}$ ) are selected in relation to roughness of surfaces and volumetric density of observed body.

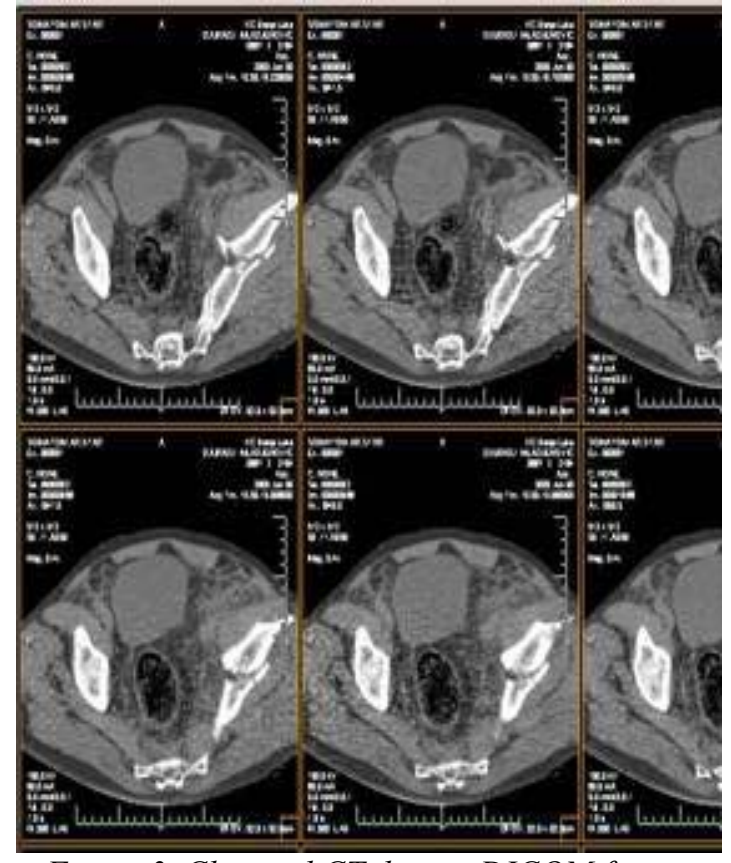

Figure 3. Classical CT data in DICOM format

Dimensional information of CT data is preserved by using DICOM file format in header part. Common series of raster images without calibration parameters of $\mathrm{CT}$ system lose this very important data.

\subsection{Image processing and edge extraction}

One can see in the figures 4 and 5 samples of edge segmentation and formation of parametric closed contours that are used later for conversion of 2.5 $\mathrm{D}$ into 3D models.

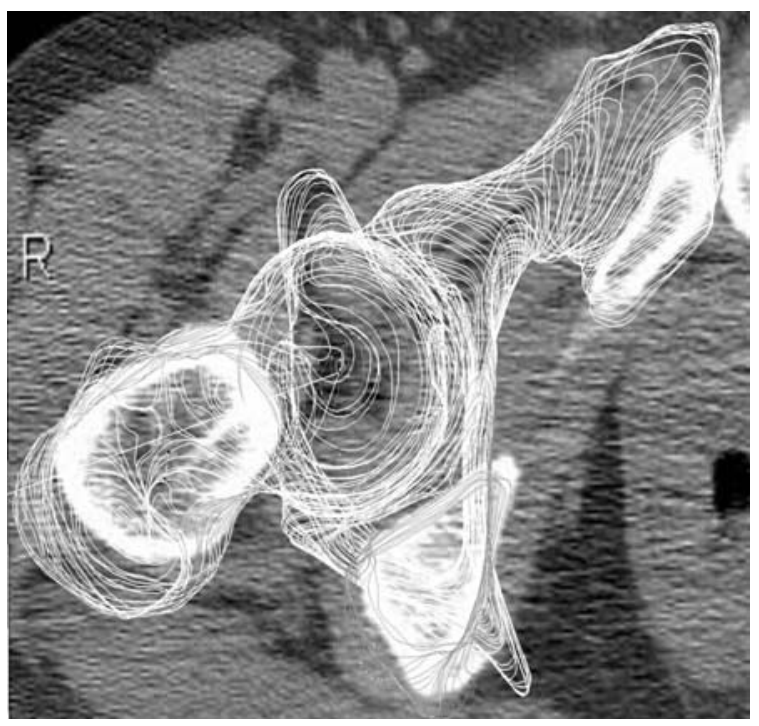

Figure 4. Top view of image processing and edge detection 
Before the edge detection, image processing is necessary. Usually, high pass and low pass filtering are used to adapt the images according to the soft and hard body tissues. With heuristic results as practical experience, certain thresholds for filtering are selected for certain kind tissues: bones, cardiovascular system, lungs, etc.

Expert systems implemented in some software like MIMICS by Materialize Co., have predefined thresholds for various body tissues.

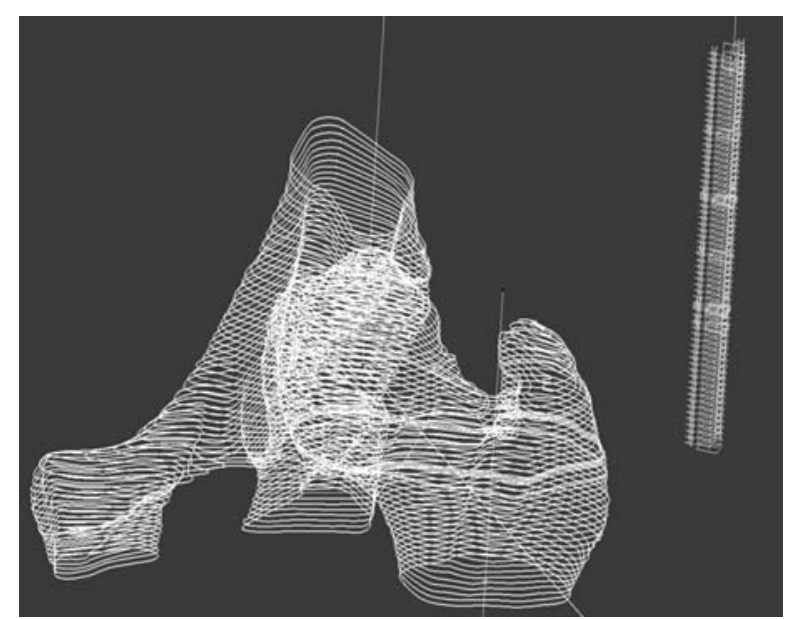

Figure 5. Isometric view of image processing and edge detection

\subsection{Conversion phase from $2 \mathrm{~d}$ to $3 \mathrm{~d}$ by cad} tools

Following the edge extraction and formation of closed contours in any corresponding slices, it is necessary to distribute them in $3 \mathrm{~d}$ space in the same way that this process was done by CT system (see the figure 6.).

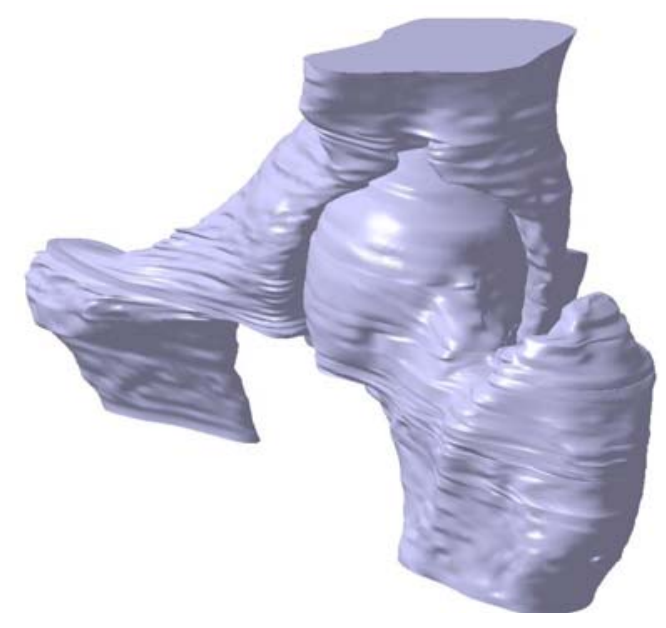

Figure 6. Isometric view of image processing and edge detection (before polishing/smoothing)
So, there is a generation of planes in parallel series at the same distance like the value of CT collimation. In this way, the same dimension transfer from CT data to the 3D model in z-axis is preserved.

The next step is the generation of $3 \mathrm{D}$ model by some of CAD applications by extrusion tools. Major challenge after extrusion of 2 dimensional contours is presented by smoothing the external and internal surfaces of odd tissues, caused by various noise produced during CT generation of data and filtering in image processing phase. The next phase is tessellation determined by allowed maximum "sag" and the length of triangles which approximate the surface.

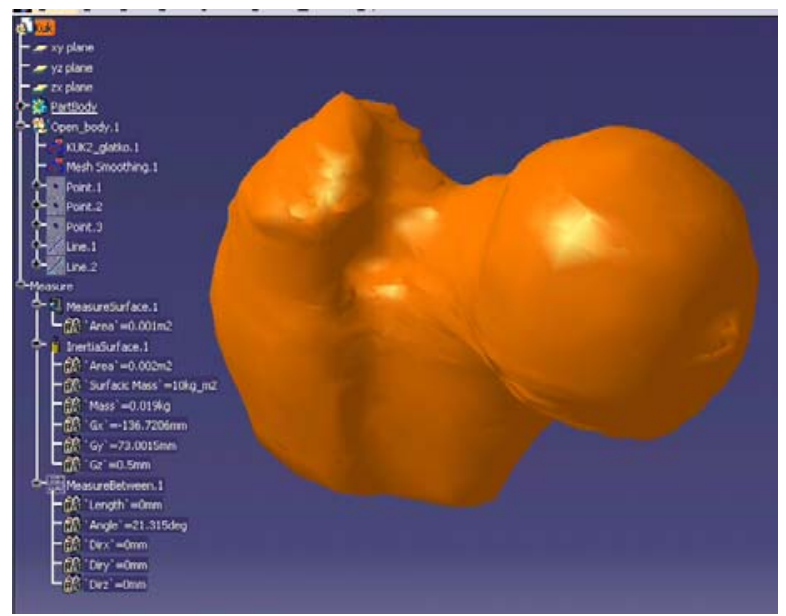

Figure 7. Tessellation and smoothing of body's surfaces

Tessellation is one of the key phases for time consumption, if one makes a mistake in preparation of tessellation parameters.

Major parameters include: "sag" and length of triangle (see figure 8.). The mentioned parameters are in the focus of the results in the chapter 4 . of this research stage. It is shown that, if one makes serious errors in parameters setting, sometimes it is impossible to finish $3 \mathrm{D}$ conversion.

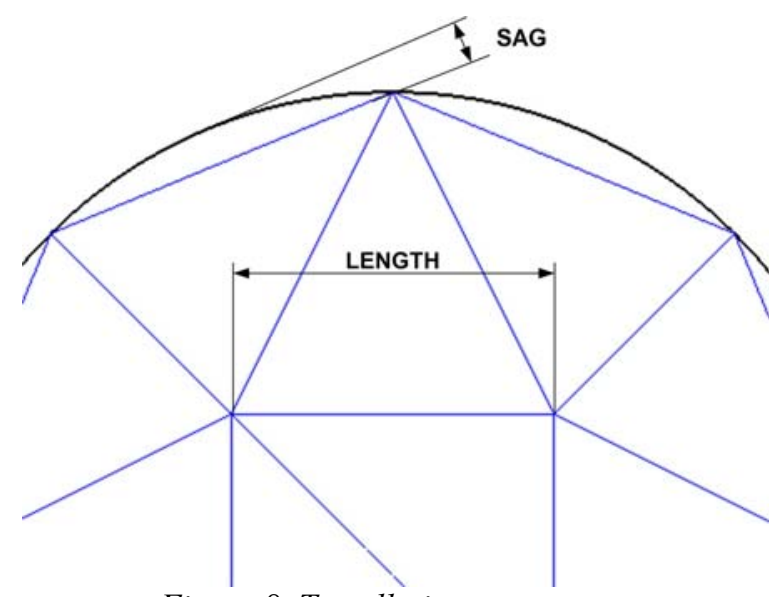

Figure 8. Tessellation parameters 
Sag represents the maximum distance between the real contour of the body and neighboring edge of tessellated triangle, which approximate the body surface. Lower sag means the closer edge of triangle to the real surface in normal direction.

Length defines the maximum nodal distance on tessellated triangle. The lower the length, the better the resolution, but the problem is presented by preprocessing time, size of stl file and time for slice preparation in RP processing.

Also, besides CAD 3D formats, there is also a format called SSD - shaded surface display based on voxels, which is also often used, but only for diagnostic work. SSD data still has binary structure like pixels in 2D images. SSD format comprises photorealistic virtual form.

If one compares MPR, SSD and CAD data, it may be noticed that MPR data has only 2D structure, while SSD has "virtual 3D" form, and it is possible to view 3D structure. But with real CAD data, it is possible to measure 3D distances, angles, surface value and volumes, or to make rapid prototyping models for implantology and computer aided surgery.

CAD models are parameterized and it is possible to customize them in virtual space for the purpose of implantology or to add the other parameterized CAD models as implants, with the aim to check the dimensions and position of implant (like Surgery Guide software tools in dentistry).

This characteristic of CAD data is very useful for design and production of individually customized implants. Also, it gives an opportunity to make kinematic and dynamic analysis of bodily movements, and also to do the FEM analysis (Finite Element methods) for stress and deformation analysis, of both implants and body tissues.

\section{THE RESULTS OF CURRENT RESEARCH}

As mentioned above, the current research is dealing with the preprocessing phases, because RP chain in medical applications is very extensive. The second or follow-up research will be focusing on processing for adaptive methods and post-processing for typical methods in medical applications.

The major problems in preprocessing phase are, as follows:

1. fusion of separate body tissues in contact, causing overlapping of extracted edges,

2. roughness of extruded surfaces, which can be smoothed during tessellation,

3. proper selection of parameters for tessella-
The first problem with projection amalgamation of two bodies in contact cannot be avoided, but it can be significantly decreased by higher resolution of CT scanning, and adjusting of filter thresholds before edge extraction. Also, during edge extraction it is possible to correct some of the most complex contours according to the previous experience and good knowledge of anatomy prediction of logical contouring.

The second problem is the roughness of extruded surfaces generated from extracted contours. This issue is caused by various noise produced in CT scanning, and throughout the preprocessing phase, the error from CT scanning ensues. It is important not to emphasize these errors but to keep them close to some average values of measures on observed components. This can be done by good filtering in image reconstruction phase. Also by good selection of low-pass filtering of image processing, some unwanted and not observed particles can be removed by smoothing. In the next step - tessellation, there is a special tool, called "mesh smoothing" that can polish the residual peaks from noised roughness.

The third problem is presented by proper selection of tessellation parameters. Certain similarities, but also significant differences, between the technical parts with many regular surfaces and human parts of body with very complex surfaces can be noticed there.

During research, it was determined that sag should be in accordance with the maximum performance of RP system and at the same time the CT resolution linked with CT collimation. The minimum collimation for typical scanning is $0,5 \mathrm{~mm}$ to $1 \mathrm{~mm}$, which is acceptable for very complex tissues like in maxillofacial area. On the other hand, the produced roughness of RP systems varies between 8-16 $\mu \mathrm{m}$, and accuracy between $100-500 \mu \mathrm{m}$ for all systems (see table 1.)

Table 1. Performance comparison of RP systems

\begin{tabular}{|c|c|c|c|}
\hline Methods & $\begin{array}{c}\text { Accuracy } \\
(\mu \mathrm{m})\end{array}$ & $\begin{array}{c}\text { Roughness } \\
(\mu \mathrm{m})\end{array}$ & $\begin{array}{c}\text { Part cost } \\
(\$)\end{array}$ \\
\hline SLA 500 & $100-120$ & 8 & 300 \\
\hline SLS 200 & $125-150$ & 12 & 300 \\
\hline FDM & 150 & 28 & 250 \\
\hline LOM & 200 & 30 & 200 \\
\hline 3D print & $400-500$ & 16 & 50 \\
\hline
\end{tabular}

So, it is acceptable to accept some sag between $0,05-0,2 \mathrm{~mm}$ for the most applications.

Also the length can vary between $0,2 \mathrm{~mm}$ to 1 $\mathrm{mm}$ for fine structures and $1 \mathrm{~mm}-3 \mathrm{~mm}$ for coarse structures and bones like femur. tion. 
Table 2. Computation results of sample cylinder triangulation (pre-assumption: maximum of sag is 0,1 $\mathrm{mm}$, according to the allowed roughness error)

\begin{tabular}{|c|c|c|}
\hline Length & Number of triangles & Size of stl files \\
\hline 50 & 404 & $16 \mathrm{~KB}$ \\
\hline 20 & 820 & $41 \mathrm{~KB}$ \\
\hline 10 & 1780 & $87 \mathrm{~KB}$ \\
\hline 6 & 2804 & $137 \mathrm{~KB}$ \\
\hline 3 & 10972 & $536 \mathrm{~KB}$ \\
\hline 1 & 189980 & $9277 \mathrm{~KB}$ \\
\hline 0,5 & 505588 & $24687 \mathrm{~KB}$ \\
\hline
\end{tabular}

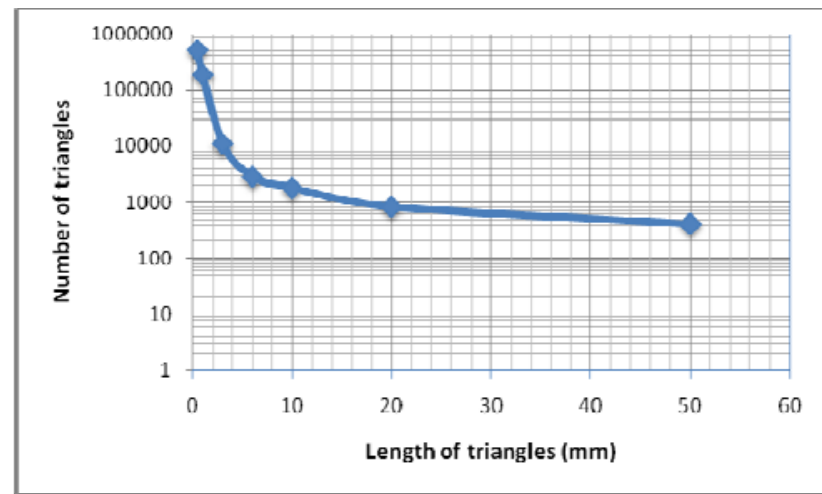

Figure 9. Relation between length of triangles and number of triangles

One can see in the table 2. and corresponding figure 9., that it is very important to select the proper set of tessellation parameters. For the testing, the cylinder was used as a sample to show the relation between length of triangles and number of triangles. The number of triangles increases drastically with the lengths less than $1 \mathrm{~mm}$ (see the figures 10, 11, 12.). But it is necessary to use these resolutions for very complex tissues.

It is evident that the problem of exponential increasing of stl files is something that will present certain challenges for the following phases. Even more, for body tissues with very irregular surfaces, it may multiply the size of stl files 3-20 times on the same volume of regular surface compared to technical parts. So, it is important to control these parameters in medical applications much more than in technical applications.

On the other hand, a convenient sag error which is feasible for RP processing is easier to select. So, for the fine body structures; the values 0,05 to $0,2 \mathrm{~mm}$ will not increase the number of triangles so fast in adaptive meshing models (see the figure 13.).

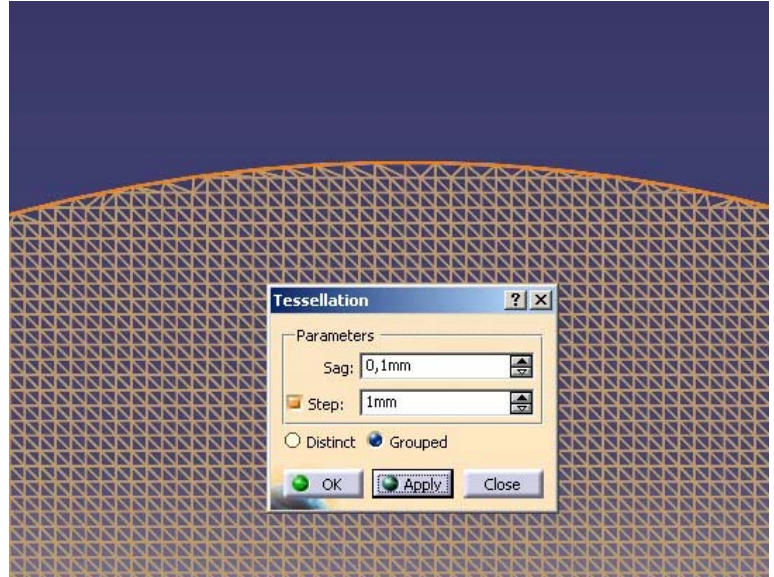

Figure 10. Meshing for sag 0,1 mm and length $1 \mathrm{~mm}$-for the finest body structures

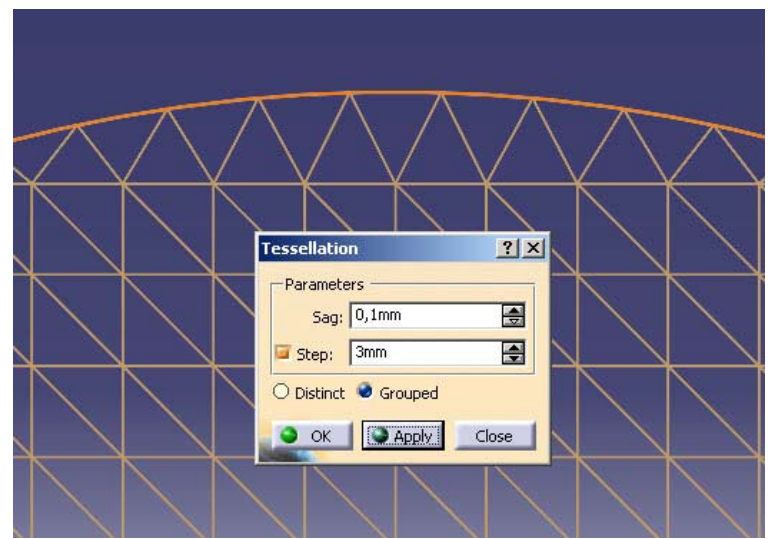

Figure 11. Meshing for sag $0,1 \mathrm{~mm}$ and length $3 m m$ - for the simple body structures

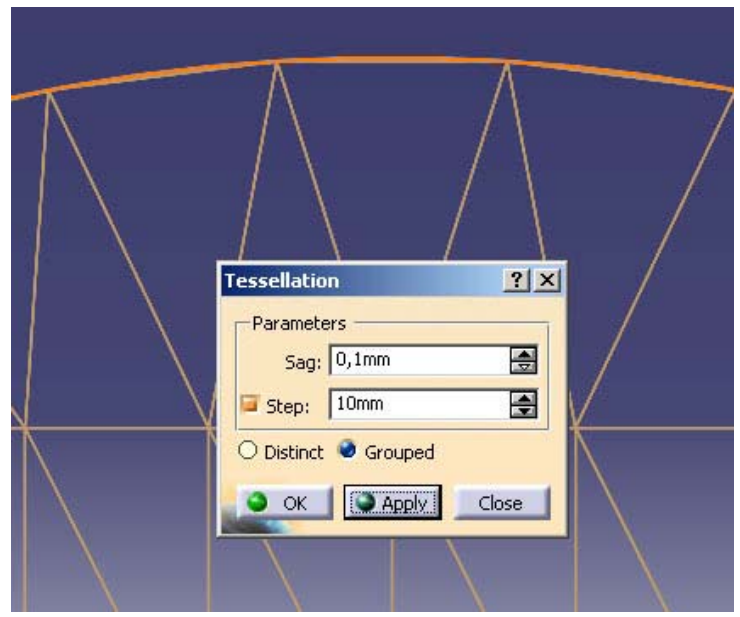

Figure 12. Meshing for sag 0,1 mm and length $10 \mathrm{~mm}$ - big tessellation triangles 


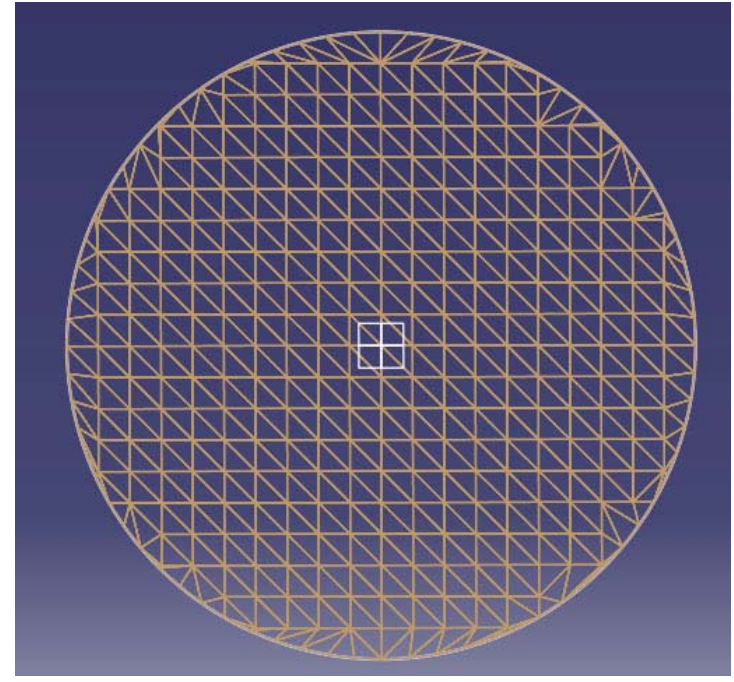

Figure 13. Meshing without adaptation of structurelarger number of triangles

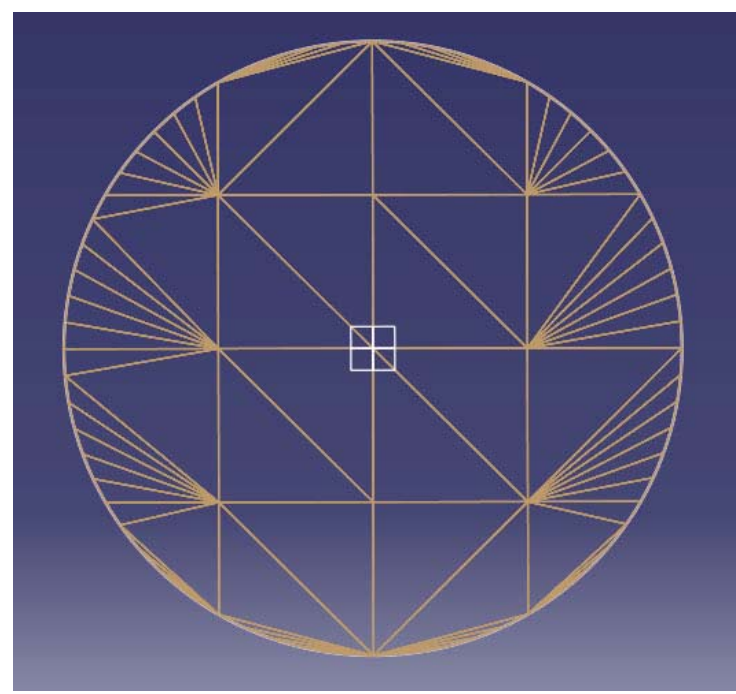

Figure 14. Meshing with adaptive structure - lower number of triangles and kept sag

\section{CONCLUSION AND FOLLOWING RESEARCH}

By this research, we succeeded in applying the Reverse Engineering and Rapid Prototyping for the practical purposes for Computer Aided Surgery in orthopedic applications in Banja Luka.

Practical using in medical applications of this research, provides some recommendations for preprocessing phase to prepare the models with optimized parameters.

The next stage of research will focus on processing and especially post processing phase with the aim to develop new methods for strengthening of RP models, by controlled coating of outer surfaces.

The next figure is a concrete presentation of computer aided surgery and measuring some important parameters for implantation.

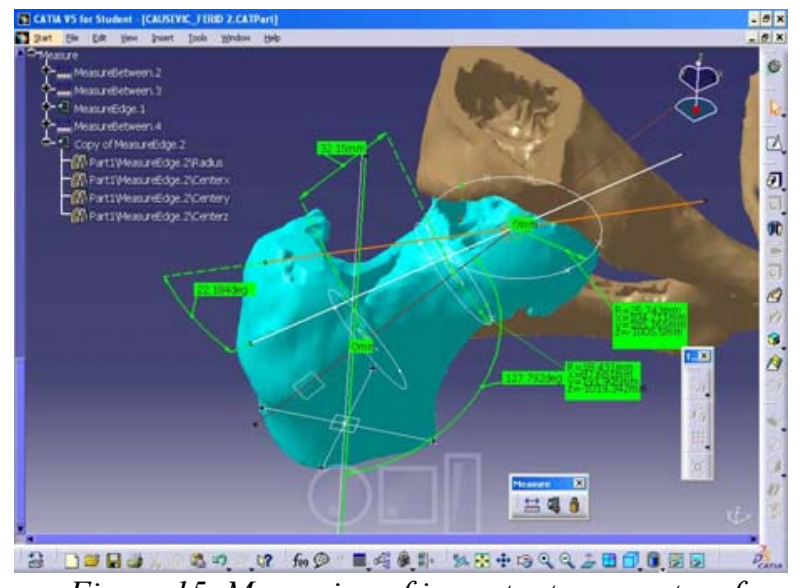

Figure 15. Measuring of important parameters for surgery preparation and implantation

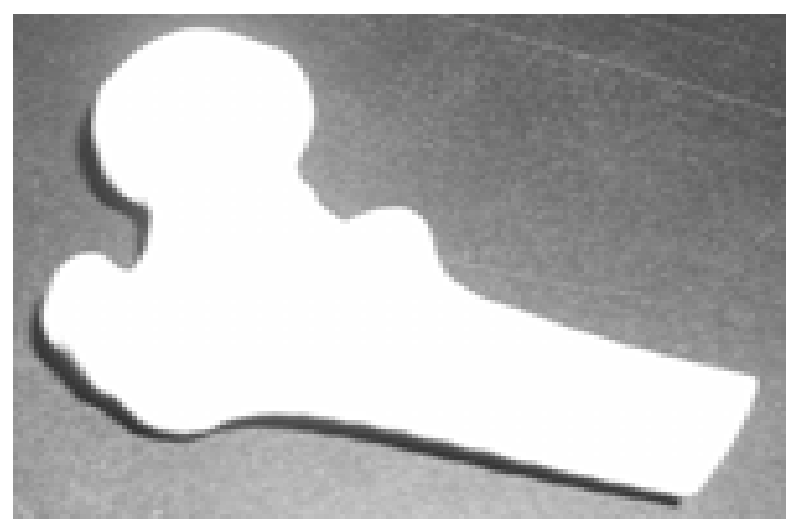

Figure 16. RP model of femur

\section{REFERENCES}

[1] I. Gibson, Advanced Manufacturing Technology for Medical Applications: Reverse Engineering, Software Conversion and Rapid Prototyping, John Wiley \& Sons Inc., (2005)

[2] A. B. M Saifullah, N. P. Mahalik and B. H. Ahn, The Need Of Technology Transfer of RP in Prototyping and Casting Industries of Developing Countries, Proceedings of the International Conference on Mechanical Engineering (2005) (ICME2005) 28-30.

[3] M. Stanojević, M. Šljivić, Identification of significant factors on the quality of surface and accuracy of $3 D$ model produced by $3 D$ Multi-Jet RPtechnology, V International Conference ДЕМИ, (2002) 153-158.

[4] N. Grujović, Definisanje parametara za ocenjivanje kvaliteta izrade i funkcionalnosti prototipa razvijenog RP tehnologijom, projekt Ministarstva nauke i životne sredine Srbije TR6224, (2006),

[5] N. Grujović, N. Milivojević, V. Milivojević, V. Dimitrijević, Đ. Grujović, Iskustva u brzoj iz- 
radi prototipova tehnologijom $3 D$ štampe, 31 Savetovanje proizvodnog mašinstva Srbije i Crne Gore, (2006) 437-442

[6] M. Plancak, Brza izrada prototipova, modela i alata, FTN Izdavaštvo, Novi Sad, (2004).

[7] M. Šljivić, Tehnologija brze izrade prototipskih proizvoda i alata - Rapid Prototyping and Rapid Tooling, Univerzitet Banja Luka, (2007)

[8] D. Šuščević, Z. Jovičić, M. Stanojević, I. Gavrankapetanović, B. Hadžihasanović, Quantitati- ve analysis of acetabulum by used $3 D$ hip joint model, XVIII International Symposium on Morphological Sciences, Serbian Academy of Sciences and Arts - SANU, Belgrade (2005).

[9] P. J. Bartolo, Virtual and Rapid Manufacturing, Proceedings of the $3^{\text {rd }}$ International Conference on Advanced Research in Virtual and Rapid Prototyping, Leiria, Portugal, (2007).

$\operatorname{soc}$

\section{ОПТИМИЗАЦИЈА ТЕХНОЛОГИЈА БРЗЕ ИЗРАДЕ ЗА НАПРЕДНЕ МЕДИЦИНСКЕ АПЛИКАЦИЈЕ}

Сажетак: Апликација две технологије Reverse Engineering и Rapid Prototyping, интензивно се развија у медицини. Ове инжењерске методе имају посебно брз развој у следећим апликацијама: компјутерски вођене операције, компјутерски вођена имплантологија, неинвазивна дијагностика из СТ и MRI података, дизајн индивидуално прилагођених имплантата.

Ово истраживање има мултидисциплинаран приступ и захтијева тимски рад експерата из различитих научних области као што су CAD дизајн, виртуелни инжењеринг, дигитална обрада слике, медицина, имплантологија. До сада, у Републици Српској, Босни и Југоисточној Европи генерално, чине се врло ријетки пионирски апликативни кораци.

Циљ овог истраживања је да се учини допринос у оптимизацији: претпроцесирања, процесирања и постпроцесирања у процесном ланцу Rapid Prototyping у медицинским апликацијама. Оптималан процес је дефинисан за различите медицинске улазне податке и њихове формате. Процес иде од интерних 3D реконструкција из CT и MRI снимка у DICOM формату, као апликације у ортопедској и максилофацијалној хирургији, протетичкој стоматологији код комплексних тоталних протеза, али такође и код екстерних реконструкција површина помоћу $3 Д$ скенирања, као естетска хирургија и реконструкцтивне хирургија, те стоматологији базирану на еластичним силиконским отисцима, итд.

Кључне речи: оптимизација, претпроцесирање и постпроцесирање, реверзни инжењеринг, компјутерски вођена имплантологија. 